胃癌根治手術後の生存率について

\begin{tabular}{cllllrr}
\multicolumn{8}{c}{ 大阪府立成人病センター外科 } & \\
岩永 & 剛 & 寺沢 & 敏夫 & 青木 & 行俊 \\
谷口 & 健三 & 山本 & 孝紀 & 日下部 & 博 \\
内山 & 節夫 & 小山 & 博記 & 松井 & 征雄 \\
今岡 & 真義 & 和田 & 富雄 & 古河 & 洋 \\
福田 & 一郎 & 甲 & 利幸 & 石川 & 治
\end{tabular}

\title{
SURVIVAL RATE AFTER GASTRECTOMY FOR STOMACH CARCINOMA
}

Takeshi IWANAGA, Toshio TERASAWA, Yukitoshi AOKI, Kenzo TANIGUCHI,

Takaki YAMAMOTO, Hiroshi KUSAKABE, Setsuo UCHIYAMA, Hiroki KOYAMA,

Yukio MATSUI, Shingi IMAOKA, Tomio WADA, Hiroshi FURUKAWA, Ichiro FUKUDA, Toshiyuki KABUTO and Osamu ISHIKAWA

Department of Surgery, The Center for Adult Diseases, Osaka

この14年間に行った 胃癌根治手術 1,353 例の術後 5 年および10年生存率は， $70.3 \%$ 抢よび $59.7 \%$ であっ た．これら根治手術例の術後成績に大きく影響する因子は, 癌進行程度 (stage), リンパ節転移度, 癌深 達度, 癌病巣周辺の間質反応程度, 癌病巣の断面の形, 大きさ等であった. その中でも最む予後に影響す るのは stage であった。

胃癌術後生存率を各 stage 間で比較すると，その差は，術後 $3 \sim 5$ 年に和いて最も大きく開くので，こ れら術後成績を比較する場合には，5年生存率でよいと考光られるが, その際, 相対生存率によって比較 するのが最も適していると思われる。

索引用䇺：胃癌の生存率, 相対生存率, 予後因子, 胃癌進行程度

\section{I. 緒 霅}

胃癌手術後の生存率は, 通常, 粗 5 年生存率で表わさ れることが多かった. ところが最近, 術後患者の追跡が 熱心に行われるよらになり,さらに 5 年以後の再発例む それ程まれでなくなって来だために，胃癌に特いても 10年生存率で手術成續が評価される機運にある。そこ で, 術後 5 年生存率と 10 年生存率の意義について検討を 加えた。また，これら術後成績に影響する因子について も既に多数の報告があるが，これも併せて検討してみた W.

\section{II. 対象および方法}

表 1 に示すように昭和36年 7 月より昭和49年12月ま でに大阪府立成人病センターにおいて手術された胃癌
表 1 対象（昭36・7月〜昭49・12月の胃痁手術例 について)

\begin{tabular}{|c|c|}
\hline 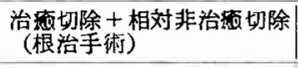 & 1353 例 $(79.8 \%)$ \\
\hline 絶対非治瀂切除 (姑息切除) & 93 例 ( $5.5 \%)$ \\
\hline ホリーブ切除 & 4 例 $(0.2 \%)$ \\
\hline 非切附 & 245 例 (14.596) \\
\hline 较 数 & 1695 例 (1009) \\
\hline
\end{tabular}

1,695 例のうち, 治漓切除および相対非治瘉切除(以下こ れらを合せて根治手術と称す) の1,353例について，術 後生存率を検討した.な括同期間の絶対非治瘾切除（以 下これを姑息切除と称す）は93例，非切除は245例であ った. 
これら手術患者は術後なるべく定期的に受診させ，受 診しないるのは葉畫により 6 カ月毎に問合わせを送付し た. 追跡患者の死亡が判明した時には，最後に䛦察した 医師を調查し，その主治医に電話をなは手紙により，組 織学的あるいは解剖検查の結果, また他覚的, 自覚的症 状，各種検査所見より再発の有無と，その部位乃至状沉 を明確にするよらに努めた。このようにして，術後患者 の生死は $100 \%$ 判明し, その死因は, 再発死亡他病死亡 に大きく分けられた。

\section{III. 結 果}

\section{1. 全手術例と全根治手術例の術後生存率}

これら手術例の手術法別にみた術後累積生存率は，因 1 亿示すように，姑息切除と非切除例が術後 3 年で $0 \%$ となったのに対し，根治手術例の 5 年生存率は $70.3 \%$,

図 1 累積生存率

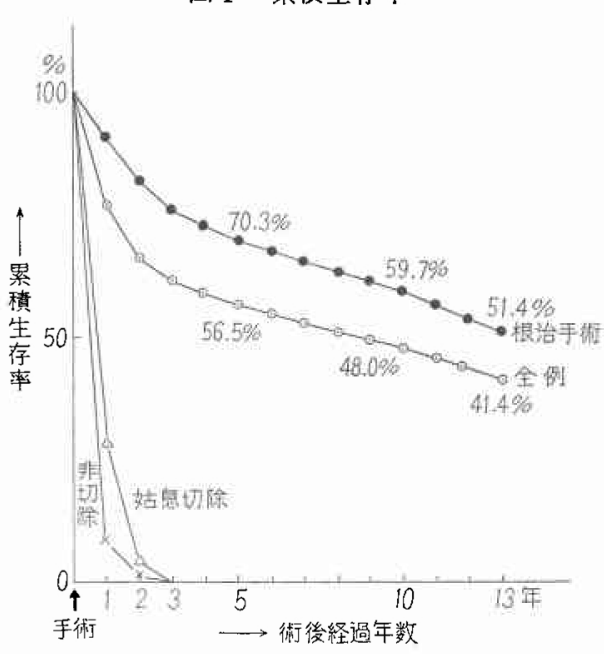

10年生存率は $59.7 \%, 13$ 年生存率は $51.4 \%$ であった。ま た全手術の 5 年と 10 年生存率は，孛れぞれ $56.5 \%$ と 48.0 \%となった.

この根治手術例について, 以下の検討を行った.

\section{5 年および10年生存率に影郎する因子}

根治手術例の術後 5 年生存率を, 各所見の程度 (段 階）別に比較してみた（図2，3），その結果，それぞ れの程度間で 5 年生存率の差が著しいものは, 癌病巣の 大きさ, 癌病巣の断面 の形 (以上図2 亿よる), 間質反 応, INF (浸潤度), 癌深達度, stage (癌進行程度), 》 ソパ節転移度 (以上図 3 による)であった。

次に, 同椂に10年生存率 (図 4, 5) で各程度 (段 階)の間の差が著明なものは, 癌病巣の大きさ, Borrma-
図2各因子の程度別飞みた 5 年生存率（その1）

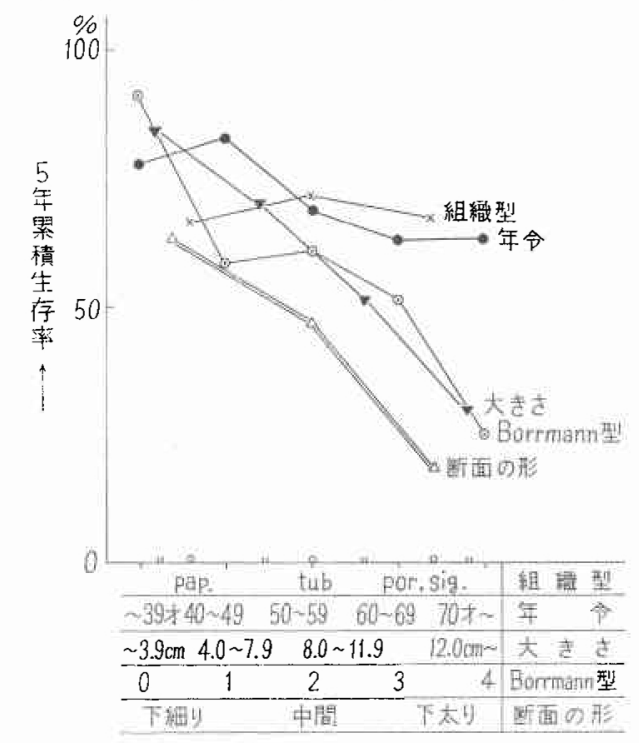

因 3 各因子の程度別にみた 5 年生存率（その 2 ）

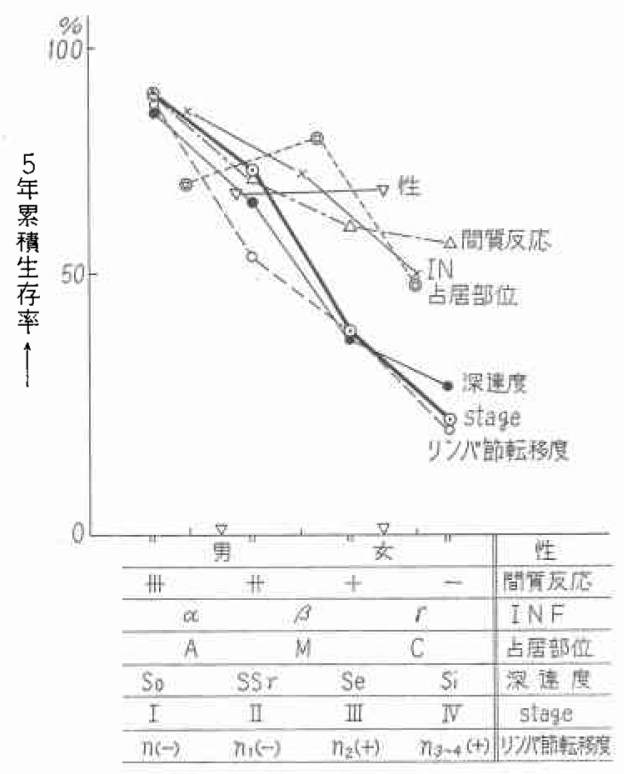

$\mathrm{nn}$ 型，断面の形 (以上図 4 亿よる), 間質反応, INF, 深達度, リン八節転移度, stage (以上図 5 による), で あった。

以上，術後 5 年怙よび10年生存率の両者ともに，それ ぞれの程度の間で最も差がみられたのは， stageであっ た. そこで次に stage 別の生存率曲線について検討を行 なった。 


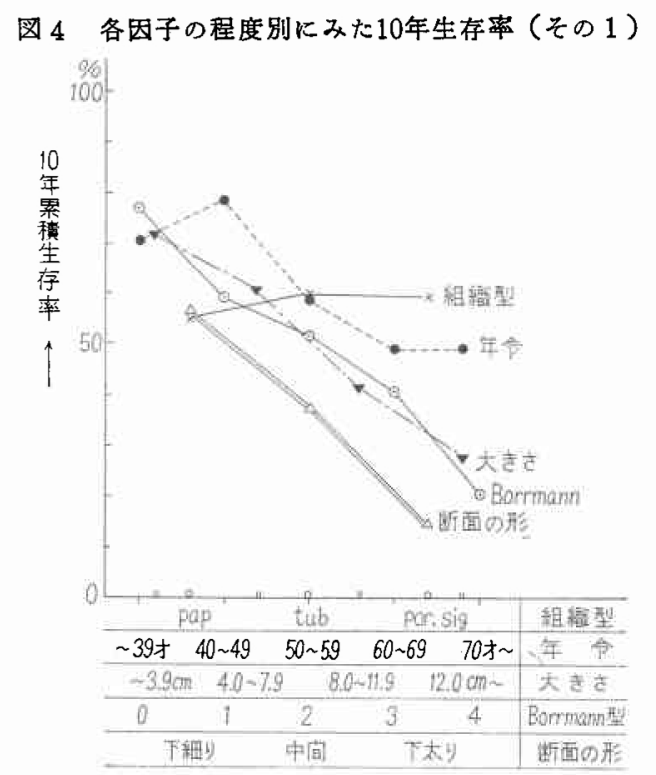

図 5 各因子の程度別にみた10年生存率（その 2)

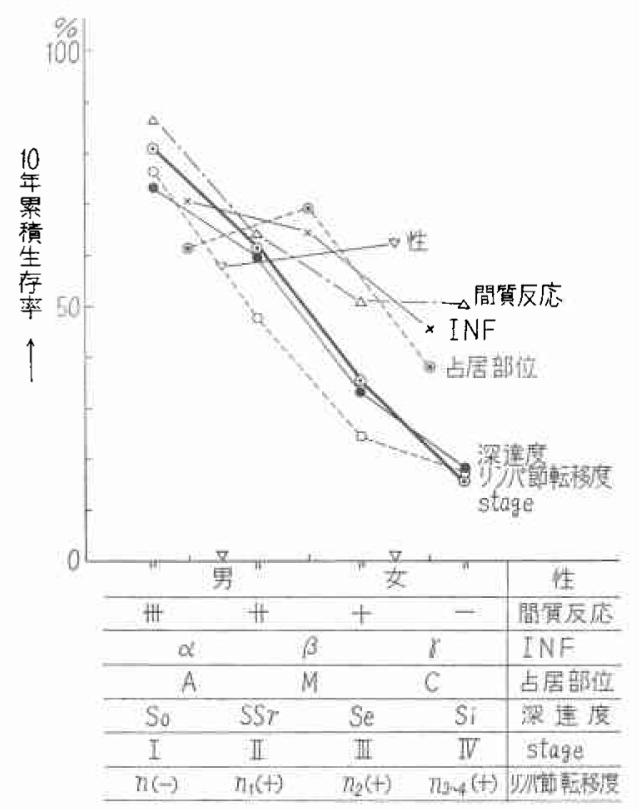

\section{3. 胃海 stage 別の術後生存率}

胃癌根治手術 1,353 例を stage 別に分けて術後の累積 生存率曲線を比較すると（図 6), 各 stage 間の生存率 の差は, 術後 $3 \sim 5$ 年で大きく開き，その後は再び徐々 に差がちぢまってくる．これを，相対生存率 (図 7) で みると，各 stage の術後生存率は，術後 1 年で既に各
因 6 stage 別累積生存率（根治手術1,353例につい $\tau)$

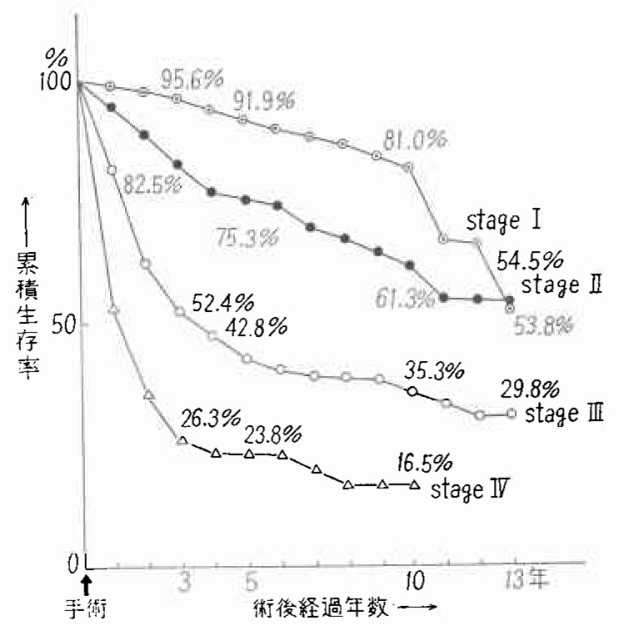

図 7 stage 別相対生存率（根治手術1,353例飞つい r)

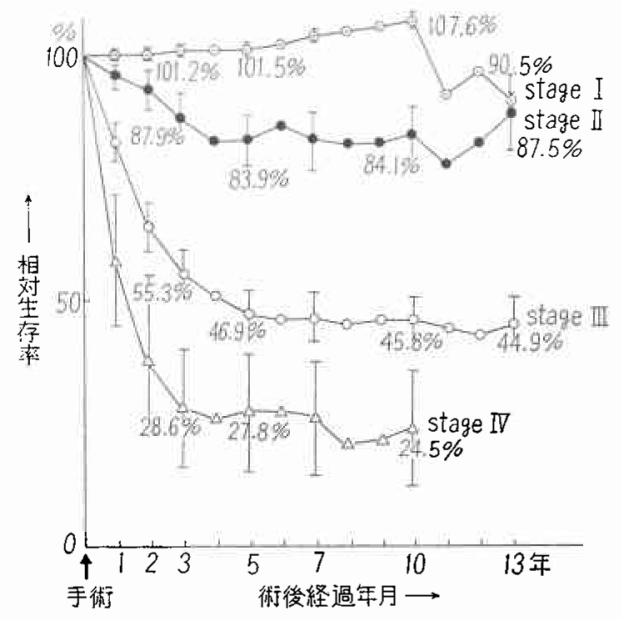

stage 間で有意差を示す.しかし，もう少し詳細にみる と, stage Iは, 術後ほぼ100\%前後であり, stage IIは. 術後 3 年以後においてほ注80\%代を維持し, stage III は。 術後 5 年以後には 44〜 47\%を持続して水平となり, stage IVは，術後 3 年以降に扣いて20\%代を堅持している。

\section{IV. 考察}

1. 胃癌術後生存率の他施設との比較

胃癌手術後の遠隔成績は, 年々良好となり, 最近の報 告に竹ける胃癌治痹切除例の 5 年生存率は 53 ～64\%であ

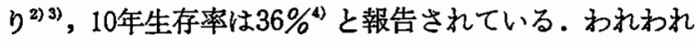
の成績は, 相対非治㾤切除例まで含めた根治手術例の 5 
年扣よび10年生存率が，それぞれ70.3\% 括よび $59.7 \%$ で，極めて良好な成績を示した。

\section{2. 術後生存率に影響する因子}

胃癌術後 5 年生存率に影響する因子として，既に多く の報告がある。

まず，癌病巣の大きさは，小さいものがよい予後を示 すとい5すの ${ }^{56)}$, Borrmann 3〜4型あるいは浸潤型では 大きなもの程，生存率が低くなるといらものがある゙る8.

癌の肉眼型としては, Borrmann 1 型または 2 型が， Borrmann 3 型または 4 型よりよい成績を示すというる $の^{799)}$ ささら限局型が浸潤型より良好な成績であった という報告 ${ }^{38)}$ が多い，癌病巣の断面の形では，井口ら ${ }^{10)}$ は, 「漏斗型」がよく，「山型」が覀いと述べわれ

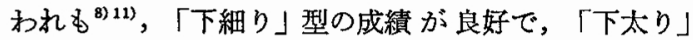
型が不良であるということをすでに何回も報告して来た ところである。

癌の組織学的所見として, 細胞異型度 (CAT), 浸潤 度 (INF) む予後に影響するといわれ7，また癌病巣 周辺の間質反応の程度, あるいは局所リンパ節の sinus histiocytosis の程度も術後成績に大きく関与するといわ れている12)13).

さらに，胃癌が粘膜固有層 $(\mathrm{m})$ より深部に浸潤して 墏膜 $(\mathrm{s})$ 飞達するまでの胃壁の深達度別飞生存率をみ ると大きな差異が認められるというるの的3778) 14115)16), リン八節の転移の有無あるいは転移度または転移個数が 術後生存率に大きな違いを示すといら報告(2)3778)15) 16)177, またこれらを合わせた癌進行程度 (stage) が極めて予後 飞影響するといら発表(2)37)8) 15)168 (は多い。

われわれの検索では，このように予後に影響する多く の因子の中でも，これら癌の進行度の総合的表現之考党 られる癌進行程度（stage）が最もその遠隔成績 に関係

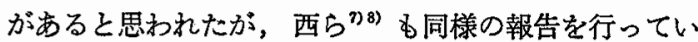
る.

\section{3. 胃癌術後 5 年以降の生存率と相対生存率}

以上の術後遠隔成績に関する検討は，主として術後 5 年生存率で検索されたものが多く，10年生存率に関する 報告は，今まではほとんどみられなかった。最近術後 10 年生存率の報告む少しずつ発表されるようになったが， それによると 10 年生存率の分析を行っても，5年生存率 と注涪同様の傾向であった ${ }^{18)}$ といわれ，また術後 5 年よ り10年までの生存率の減少は，ぞの項目汇未いても大き く変化するるのは少ない副と述べられている。われわれ の結果でも，図 2 と図4，図3 と図 5 に示したように, 術
後 5 年と 10 年生存率でほぼ同様の傾向を示した。

われわれ201 は，かつて胃癌術後 5 年までを 1 年毎に区 切って, 粗生存率と累積生存率とを比較した結果, 両者 ともほとんど同し值を示し，累積生存率の有効性を証明 した．その後は術後生存率の検討に際しては累積生存率 を用いることが多いが，この累積生存率は，その数値を 基にして相対生存率を算出することる可能で，便利であ ると思われる。

胃癌術後の相対生存率 ${ }^{211}$ は, 胃癌治療を受けた患者が 一般人にくらべてどれ位生存し得るかを表現しており， また $2 つ 以 上 の$ 症例群を比較することにより癌治療の真 の評洒が可能なので，極めて意義がある表現法と思われ る.この相対生存率を用いて, 胃癌の術後生存曲線を stage 別にかいてみると，図７亿示したように，術後 3 年〜 5 年でお互いの差が開いて，それ以降の生存曲線は 各 stage ともほほ平行となった。

胃癌症例の術後死因を大き再発死 と他病死飞分 て, 各 stage 別飞衍後各年の死亡数の推移をみると（図 8 ), 再発死亡数は, 術後 3 年までは極めて多数にみら れるが，4年以降は激減している. stage 別では, stage III とIVがやはり術後 4 年までは多いが，その後は減少す るのにくらべて, stage I とIIでは, 術後 4 年以降でる な特みられる。一方，他病死は，術後 5 年以降でむかな りみられ，6年以後は再発死亡例数とほぼ同数となる。

因 8 胃癌根治術後の死亡数の推移

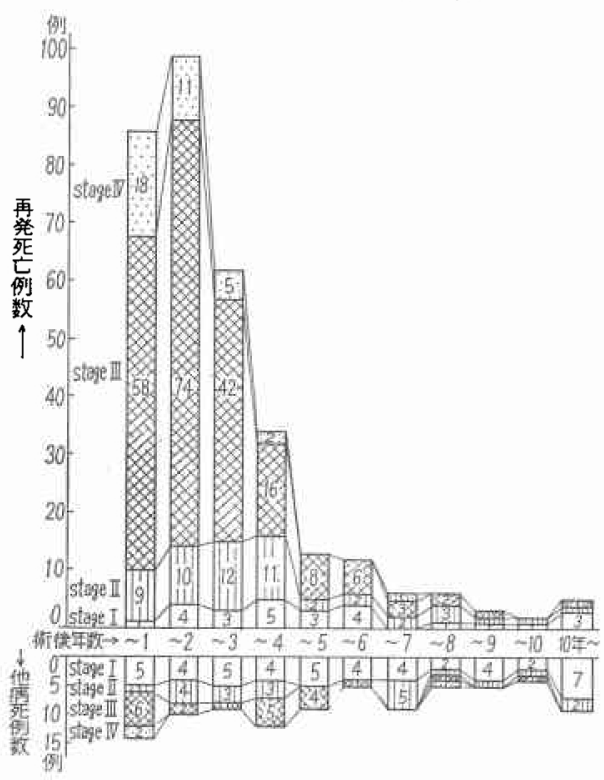


とくに stage I 症例の他病死は，術後各年を通してほぼ 同数の死亡がみられた。すなわち，術後長年月を経過す ると再発死が減少し, stage Iに多くみられる他病死が 比較的增加してくる.このため術後 5 年以降では, 各 stage の生存率の差がちぢまり，一般人とほぼ平行した 生存曲線を画くようになることがよく判る。このような ことにより，胃癌そのものの因子による遠隔成績に対す る影響は, 通常 $3 \sim 5$ 年で判定が可能である. 最近胃癌 の術後成績も10年生存率で以って判定しないといけない といら意見も出されているが，単に胃癌術後生存率に影 響する因子を比較するだけならば，5年生存率でよいと いうことであるう．とくに，これを相対生存率で表わす のが最も適切と考兄られる.もちろん，術後 5 年以後に も癌再発がみられる 討することは，な技必要であることは論を待つまでむな い.

\section{v. 結 嘉}

（1）昭和 49 年末むでの 13 年半の間に大阪府立成人病 センターで手術された胃癌1，695例のらち，根治手術(治 癒切除之相対非治疻切除) が行われた 1,353 例の術後 5 年，10年拉よび13年生存率は，それぞれ70.3\%，59.7\% および51.4\%であった。

（2） 根治手術例の術後 5 年あるいは 10 年生存率に大 きく影響する因子は，癌進行程度 (stage)，リンパ節転 移度, 癌深達度, 癌病策の大ささ, Borrmann 型, 癌病 巣の断面の形, 癌組織の浸潤度 (INF), 癌病巣周辺の 間質反応程度,であった。これらの中で最も術後遠隔成 績に影響を及ぼすものは stage で出った。

（3）胃癌術後生存率を各 stage 間で比較すると，そ の差は，術後 $3 \sim 5$ 年に拈いて最る大きく開き，それ以 降はその差が縮少した。これは，術後早期には再発死亡 がとくに進行した胃癌症例で多くみられたのに対し， 術後長期間経過してからは, 他病死の相対的頻度が増加 し，とくに早期の胃癌症例で比較的高率にみられたため であった。

（4）以上より, 術後の生存率は, 相対生存率で表現 するのがよく，これによると各 stage とも術後 $3 〜 5$ 年 で生存率の值はほ注一定化しだ。このことより，胃癌術 後生存率汇影響する因子を単に比較するのみならば，術 後 5 年生存率で以って行ってよいと考学られた。

\section{文嗝}

1) 岩永 㓮はか：胃癌晩期再発例の検討一外科臨 床の立場から一。胃之腸，12:21一 $31 ， 1977$.

2) 井口 潔ほか：われわれ最近の胃癌手術の遠隔

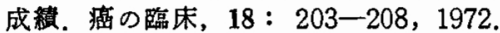

3) 高木国夫：胃癌。癌の臨床, 21 : 1136-1143, 1975.

4) 高木国夫注か：胃癌の遠隔成蹟。日外会誌, 78, $852-856,1977$

5) Comfort, M.W. et al.: Small gastric cancer, A.M.A. Arch. Int. Med., 94: 513-524, 1954.

6)岩永剛：胃癌の大きさ。成人病，10:1一9, 1969.

7) 西 满正汪か：胃瘦の 5 年生存率一とくに進行 船について一. 胃と腸, $4: 1089-1100,1969$.

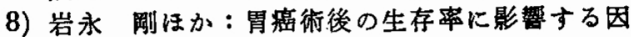
子. 日癌治, $6: 156,1971$.

9) Steiner, P.E. et al.: Gastric cancer: Morphologic factors in five-year survival after gastrectomy. Amer. J. Pathol., 24: 947-969, 1948.

10）井口 潔ほか：発育ハターンからみた胃癌の予 後一とくに進行胃癌を中心として一, 瘦の臨 床, $14: 472-480,1968$

11）神前五郎ほか：胃癌の攀膜浸潤と早期腹膜再 発。日澏治, 3：148-149，1968.

12) Black, M.M. et al.: Microscopic structure of gastric carcinomas and their regional lymph nodes in relation to survival. Surg. Gyn. Obst., 98: $725-734,1954$.

13）大森幸夫注か：癌の進展と生体の反応像につい て。最新医学, 18：613-625, 1963.

14) 三輪 潔：全国集計からみた pm 胃癌。胃と 腸, 11：847-853，1976.

15) Hoerr, S.O.: Prognosis for carcinoma of the stomach. Surg. Gyn. Obst., 137: 205-209, 1973.

16) 神前五郎ほ加：胃癌。外科治療, $30: 59$ - 63, 1974.

17) Moore, G.E. et al.: Carcinoma of the stomach. The validity of basing prognosis upon Borrmann typing or the presence of metastases. Surg. Gyn. Obst., 87: $513-518,1948$.

18）藤巻雅夫ほか：われわれの切除胃癌症例の遠隔 成樍について，日外会誌，78，856-859，1977。

19）岡島邦雄ほか：10生率からみた胃癌の予後，日 外会誌, 78, 臨時增刊号 : 140, 1977.

20)神前五郎ほか：成人病センターに於付る胃癌手 術例の予後について。成人病, 9:21-33, 1968

21) Axtell, L.M.: Computing survival rates for chronic disease patients. A simple procedure. J.A.M.A., 186: 1125-1128, 1963. 